\title{
Pelatihan Pembuatan Media Pembelajaran Buku Digital Menggunakan Flipbook Pada SDIT Sullamul 'Ulum
}

\author{
Fauzi Yusa Rahman*1, Erfan Karyadiputra ${ }^{2}$, Agus Setiawan $^{3}$, Indu Indah Purnomo 4 \\ 1,2,3,4 Program Studi Teknik Informatika, Fakultas Teknologi Informasi, \\ Universitas Islam Kalimantan MAB Banjarmasin \\ *e-mail: fauziyusarahman@gmail.com¹ erfantsy@gmail.com² \\ agusteknik08@gmail.com ${ }^{3}$ indumbc@gmail.com ${ }^{4}$
}

\begin{abstract}
Learning media is an important part of learning activities. Books are part of learning media that can be displayed following the progress of the times and advances in technology. Teachers play a very important role in learning at school, usually teachers provide material to students using textbooks, whiteboard media or using slides on Microsoft Power Point. In the implementation of this community service activity, training for SDIT Sullamul 'Ulum teachers on how to make digital books using flipbooks, such as using existing tools, making the content in digital books presented interesting so that students are easy to understand and can be applied to Learning Activities. Based on the results of the practice carried out, participants can design and create digital learning media using flipbooks in accordance with the processes and stages that have been given by the presenters so that a good learning media is produced and with a more attractive appearance.
\end{abstract}

Keywords: SDIT Sullamul 'Ulum, Digital Media, Flipbook

\begin{abstract}
Abstrak
Media pembelajaran menjadi bagian penting dalam kegiatan pembelajaran. Buku mejadi bagian dari media pembelajaran yang bisa ditampilkan mengikuti kemajuan dari zaman dan kemajuan dari teknologi. Guru berperan sangat penting dalam pembelajaran di sekolah, biasanya guru memberikan materi kepada anak didik menggunakan buku paket, media papan tulis atau menggunakan slide pada microsoft power point. Pada pelaksanaan kegiatan pengabdian kepada masyarakat ini melakukan pelatihan kepada guru-guru SDIT Sullamul 'Ulum bagaimana cara membuat buku digital menggunakan flipbook, seperti menggunakan tools yang ada, membuat konten dalam buku digital yang disajikan menjadi menarik sehingga peserta didik mudah untuk memahaminya dan dapat diterapkan pada kegiatan pembelajaran. Berdasarkan hasil dari praktek yang dilakukan peserta dapat merancang dan membuat media pembebelajaran digital menggunakan flipbook sesuai dengan proses dan tahapan yang sudah diberikan oleh pemateri sehingga dihasilkan suatu media pembelajaran yang baik dan dengan tampilan yang lebih menarik.
\end{abstract}

Kata kunci: SDIT Sullamul 'Ulum, Media Digital, Flipbook

\section{PENDAHULUAN}

Kemajuan teknologi pada masa sekarang membuat banyak terjadi perubahanperubahan dari proses kehidupan manusia di mulai pada era informasi ke era digital pada berbagai bidang (Fitria 2018). Penggunaan dari teknologi, informasi dan komunikasi sebagai bagian dari media pembelajaran menjadikan salah satu langkah efektif dan efisien yang digunakan pengajar dalam memajukan kualitas dan kuantitas pendidikan yang ada di Indonesia. Teknologi, informasi dan komunikasi menjadi suatu solusi dari masalah yang dijumpai dalam dunia pendidikan, terdapat banyak kemudahan dari penggunaan teknologi dan juga kemutakhiran, ketepatan dan kecepatan dalam proses menyampaikan informasi yang membuat teknologi, informsi dan komunikasi menjadi sangat penting dalam berbagai macam bidang termasuk dalam bidang dunia pendidikan.

Metode yang dilakukan dari belajar mengajar adalah suatu proses komunikasi yang dilakukan dari pengajar (guru) kepada peserta didik (siswa), menjadikan media 
yang diterpakan oleh pengajar dalam melaksanakan kegiatan pembelajaran disebut dengan istilah media pembelajaran. Menurut (Ayuningtyas et al. 2018) mengemukakan dalam penerapan proses komunikasi akan melibatkan 3 (tiga) bagian utama yaitu, pertama adalah bagian yang berperan dalam mengirim pesan (guru), kedua adalah bagian yang berperan sebagai penerima pesan (murid), dan ketiga adalah bagian dari pesan tersebut yang berperan sebagai materi dari pelajaran. Selama ini guru masih masih banyak yang menerapkan metode konvensional saat melaksanakan pengajaran di kelas berupa ceramah, cara yang digunakan oleh guru dalam mengajar masih monoton dan tidak terlalu menarik, guru dalam memberikan materi pelajaran masih menerapkan media pembelajaran berupa buku paket dan mengguakan papan tulis dalam menyampaikan materi (Sari et al. 2021). Media yang digunakan dalam proses pembelajaran adalah salah satu faktor penting dari metode pembelajaran yang diterapkan guru sebagai cara dalam memberikan informasi antara pengajar kepada peserta didik, sehingga dapat tercipta keadaan pembelajaran yang efektif dan efisien. Media pembelajaran mempunyai fungsi serta peran sebagai pembawa berbagai informasi dari sumber informasi kemudian informasi tersebut diteruskan kepada penerima informasi. Sedangkan metode yang dilakukan dalam penyampaian media pembelajaran yang diterapkan guru merupakan suatu prosedur yang akan membantu peserta didik untuk menerima dan memproses informasi menjadi pemahaman dasar dari kumpulan informasi tersebut menjadi wacana ilmu pengetahuan (Wahyuliani et al. 2016).

Media pembelajaran menjadi bagian penting dalam kegiatan pembelajaran. Buku menjadi bagian dari media pembelajaran yang bisa ditampilkan mengikuti kemajuan dari zaman dan kemajuan dari teknologi. Media pembelajaran juga akan meningkatkan proses komunikasi antara pembelajar dengan pengajar(Desyanti, Muztazihim Suhaidi 2019) .Teknologi smartphone pada masa sekarang ini sudah digunakan oleh seluruh kalangan masyarakat, tidak terkecuali oleh peserta didik di sekolah. Jadi sangat perlu adanya usaha yang harus dilakukan oleh pengajar untuk memanfaatkan teknologi dari smartphone dalam menunjang proses pembelajaran (Okra \& Novera 2019). Buku digital merupakan salah satu media publikasi berupa teks dan gambar berbentuk digital yang diproduksi, diterbitkan, dan dapat dibaca melalui komputer atau alat digital lain (Andina 2011). E-book merupakan singkatan dari electronic book (buku elektronik), sebuah bentuk dari buku yang dapat dibuka secara elektronik melalui perangkat komputer. Sedangkan interaktif merupakan kegiatan saling melakukan proses interaksi (hubungan dua arah) antara media dengan yang menggunakan media. Guru yang menerapkan media pembelajaran saat melaksanakan proses pembelajaran akan mempermudah siswa guna memahami materi-materi yang dibahas dalam pelajaran sehingga akan memperoleh hasil belajar yang baik dan memuaskan, dengan hasil belajar yang baik dan memuaskan maka tujuan dari pembelajaran bisa dicapai dengan hasil maksimal. Selain itu, penggunaan media pembelajaran dalam proses pembelajaran membuat siswa tidak terfokus hanya kepada guru yang memberikan materi (Wahyuningtyas \& Sulasmono 2020).

Penerapan dalam pembuatan media pembelajaran buku digital menggunakan flipbook menggunakan sarana internet yang akan digunakan dalam membuat buku digital oleh pengajar dan saat membuka hasil dari buku digital oleh peserta didik. Pemanfaatan media internet sebagai salah satu sumber belajar akan memudahkan siswa untuk mengakses berbagai sumber informasi yang tersedia, karena dengan menggunakan media internet dapat membantu dalam meningkatkan taraf hidup melalui pendidikan. Menggunakan media internet juga dapat mengakses berbagai referensi, baik berupa hasil penelitian, maupun artikel hasil kajian dalam berbagai 
bidang. Berbagai informasi yang sudah ada dan dapat diakses melalui media internet sudah terjadi di seluruh dunia (global world) (Sasmita 2020).

Sekolah Dasar Islam Terpadu Sullamul 'Ulum merapakan salah satu sekolah dasar swasta yang beralamat di Gambut, Kabupaten Banjar, Kalimantan Selatan. Sekolah ini sudah menerapkan pembelajaran menggunakan kurikulum 2013. Guru berperan sangat penting dalam pembelajaran di sekolah, biasanya guru memberikan materi kepada anak didik menggunakan buku paket, media papan tulis atau menggunakan slide pada microsoft power point. Pada pelaksanaan kegiatan pengabdian kepada masyarakat ini melakukan pelatihan kepada guru-guru SDIT Sullamul 'Ulum bagaimana cara membuat buku digital menggunakan flipbook, seperti menggunakan tools yang ada, membuat konten-konten yang akan ditampilkan menjadi lebih menarik sehingga peserta didik lebih mudah untuk mengerti, memahami dan juga dapat diterapkan pada kegiatan pembelajaran.

\section{METODE}

Metode yang digunakan dalam pengabdian kepada masyarakat ini meliputi persiapan pelaksanaan kegiatan, proses pelatihan yang akan dilaksanakan, pendampingan hingga melakukan evaluasi setelah kegiatan selesai dilaksanakan. Tujuan dari penerapan metode ini adalah memberikan pemahaman secara umum terkait pembuatan media pembelajaran buku digital menggunakan flipbook yang meliputi pengenalan tampilan website, menu-menu yang bisa digunakan, tujuan dari pembuatan, serta manfaat yang akan dihasilkan. Pada tahap persiapan, penulis terlebih dahulu melakukan observasi terkait penentuan tema yang akan dijadikan materi pada pelatihan, kemudian dilakukan serangkaian persiapan lain seperti mempersiapkan materi pelatihan dan mempersiapkan media penyampaian kepada peserta dengan menggunakan presentasi yang akan dilakukan oleh ketua pengabdian. Setelah persiapan dari kegiatan pembuatan media pembelajaran buku digital menggunakan flipbook ini selesai dilakukan, dilanjutkan dengan tahap proses implementasi program pengabdian. Kegiatan implementasi pada pelaksanaan pengabdian kepada masyarakat dilaksanakan dengan tahapan:

1. Ketua pelaksana dari pengabdian kepada masyarakat memberikan materi tentang media pembelajaran buku digital menggunakan flipbook.

2. Melaksanakan praktikum secara langsung kepada guru sebagai peserta dalam pembuatan media pembelajaran buku digital menggunakan flipbook.

3. Peserta mengikuti dan melakukan praktikum secara langsung dalam pembuatan media pembelajaran buku digital menggunakan flipbook dengan perangkat yang sudah disediakan dan di bantu oleh anggota pengabdian kepada masyarakat. Bila peserta memiliki masalah dalam pembuatan media pembelajaran akan dipecahkan secara langsung oleh pemateri.

Pada Gambar 1 merupakan alur dari metode pelaksanaan kegiatan dalam pelatihan pembuatan media pembelajaran buku digital menggunakan flipbook yang diterapkan. 


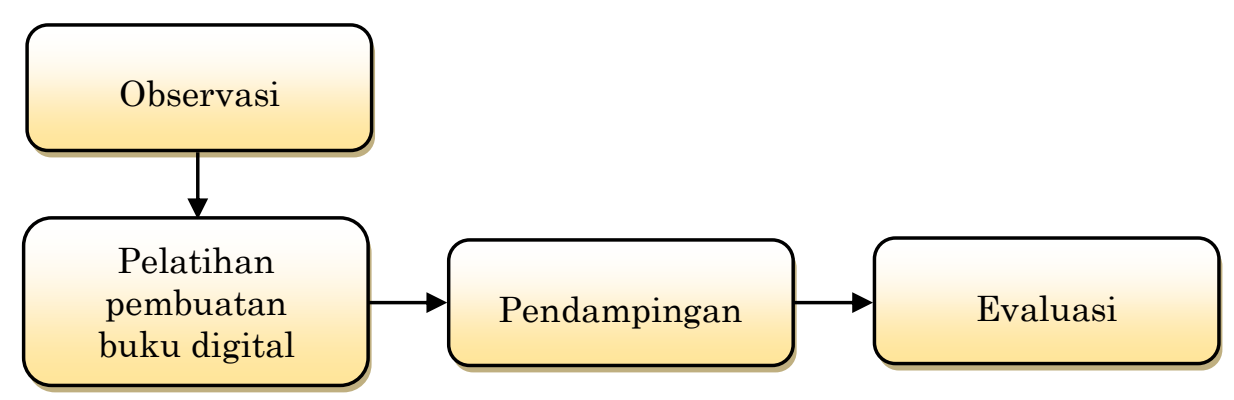

\section{Gambar 1. Alur Metode Pelaksanaan Kegiatan}

Pada akhir pelaskanaan kegiatan pengabdian, peserta mengisi kuisioner yang diberikan tim pengabdian masyarakat sebagai tanggapan terhadap kegiatan yang sudah dilakukan.

\section{HASIL DAN PEMBAHASAN}

Kegiatan pelaksanaan pengabdian kepada masyarakat dilakukan pada tanggal 18 September 2021 pada SDIT Sullamul 'Ulum yang dihadiri oleh guru-guru sebagai pengajar anak didik dikelas. Pelaksanaan pada kegiatan di mulai dengan sambutan ketua pengabdian masyarakat, kemudian dilanjutkan dengan pemaparan materi oleh ketua pengabdian kepada masyarakat.

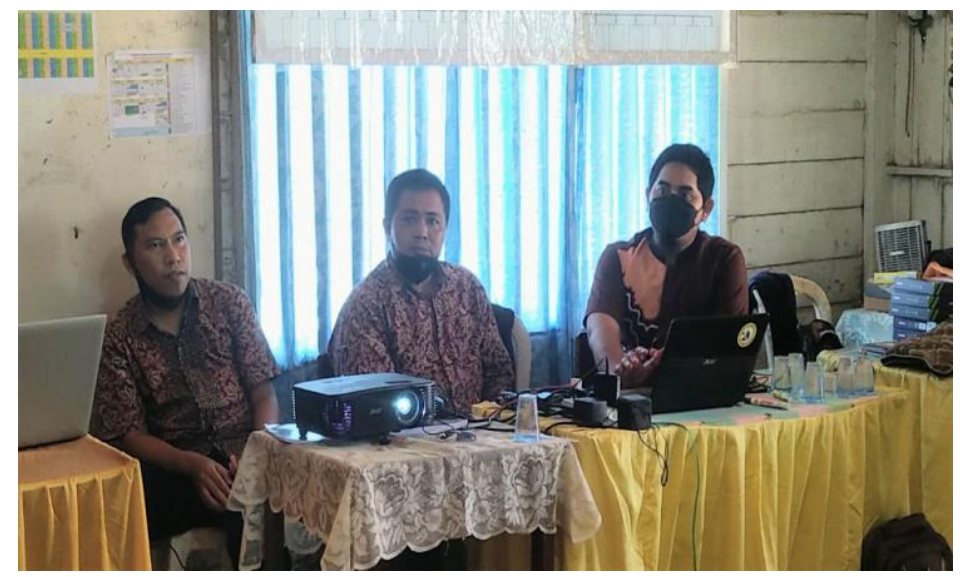

Gambar 2. Ketua dan anggota pengabdian kepada mayarakat

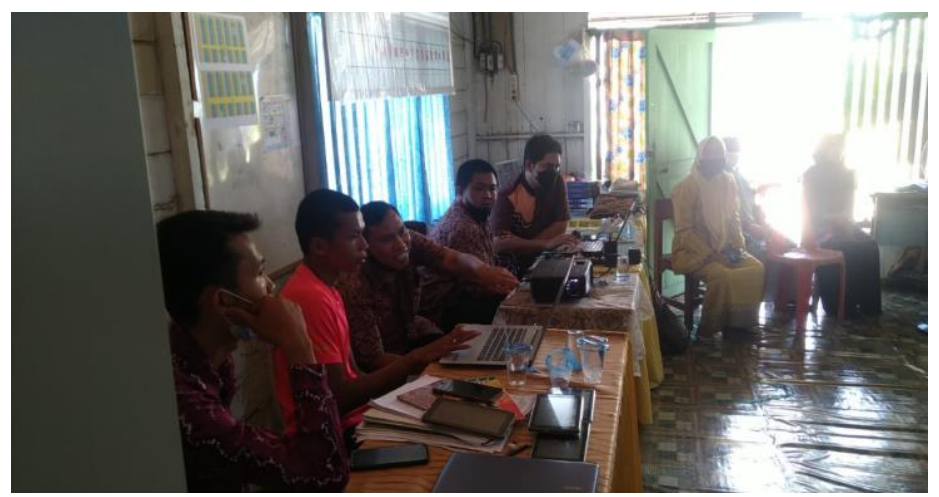

Gambar 3. Anggota pengabdian memberikan pengarahan kepada peserta 


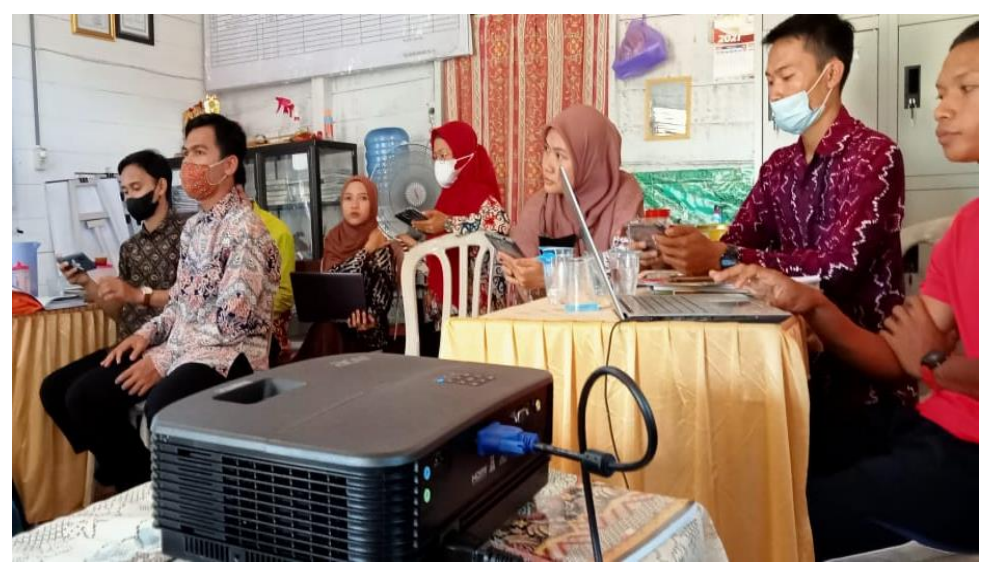

Gambar 4. Antusias peserta dalam mengikuti pelatihan

Pelaksanaan kegiatan kemudian dilanjutkan degan melakukan praktek secara langsung menggunakan komputer atau smartphone peserta mengenai penggunaan flipbook dalam pembuatan media pembelajaran buku digital, yaitu:

1. Membuat account pada website membuat buku digital, yaitu https://flippingbook.com/

2. Membuat materi pembelajaran menggunakan microsoft power point kemudian di simpan ulang dengan tipe file .pdf.

3. File materi pembelajaran kemudian di unggah pada website.

4. Melakukan modifikasi tampilan pada materi pembelajaran dengan menumenu yang telah disediakan pada halaman website.

5. Membuat hasil akhir dari flipbook untuk memberikan link halaman kepada kepada peserta didik.

Adapun hambatan yang sempat ditemui dalam proses pelaksanaan pengabdian kepada masyarakat pada SDIT Sullamul 'Ulum adalah kurangnya kemampuan dari peserta kegiatan dalam melakukan praktek secara langsung, namun hambatan tersebut dapat diselesaikan oleh ketua dan anggota pengabdian masyarakat sehingga keterampilan dari peserta dalam melakukan praktek dapat dioptimalkan.

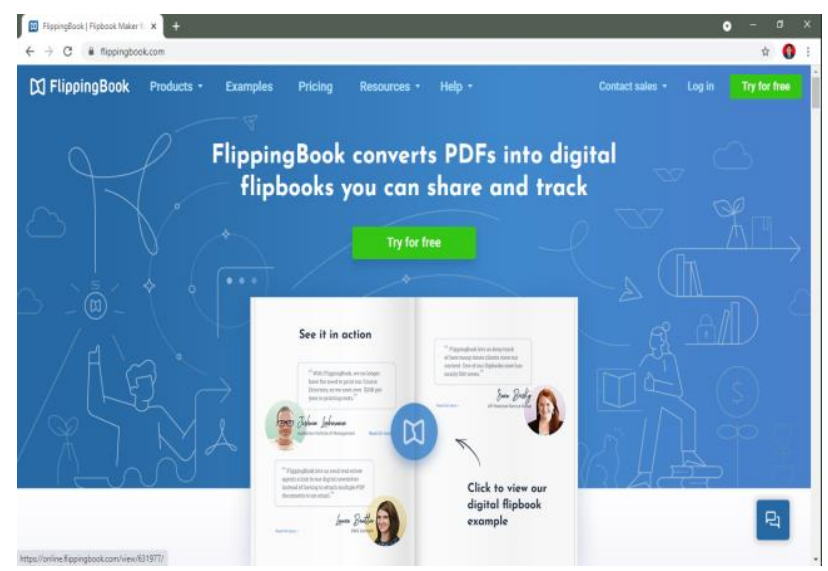

Gambar 5. Halaman Website Yang Digunakan Untuk Membuat Media Pembelajaran Digital Flipbook 


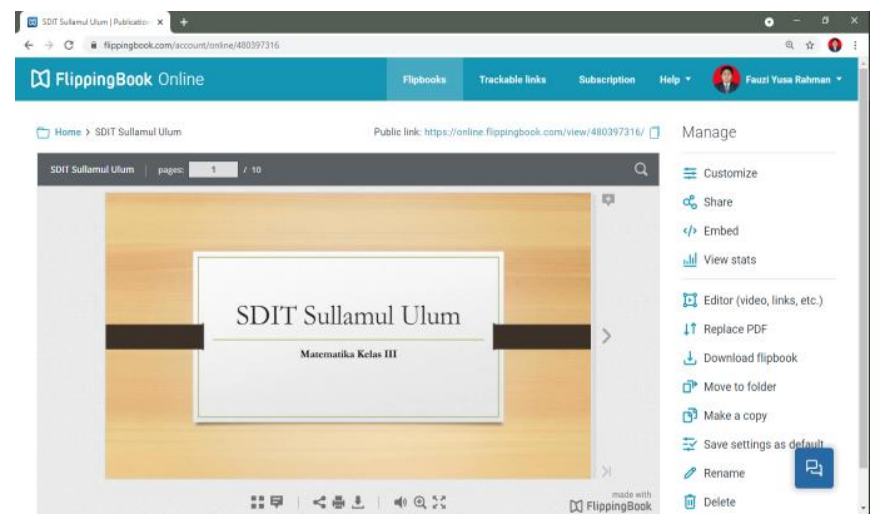

\section{Gambar 6. Hasil Dari Peserta Dalam Mempraktekan Pembuatan Buku Digital Menggunakan Flipbook}

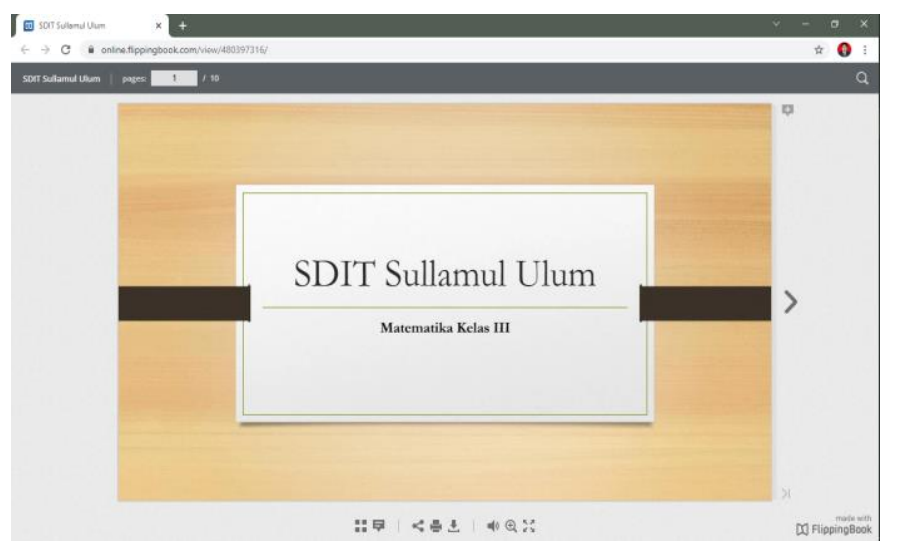

Gambar 7. Hasil Pembuatan Buku Digital Menggunakan Flipbook.

Kegiatan ditutup dengan pengisian kuesioner oleh peserta sebagai tanggapan terhadap kegiatan yang dilaksanakan. Pengisian kuesioner dilakukan dengan menulis jawaban pada kertas dan kemudian dimasukan ke dalam amplop yang sudah disediakan dan diserahkan kepada tim pengabdian masyarakat. Kuesioner ini dilakukan untuk mengetahui respon para peserta mengenai kegiatan pelatihan. Kuisioner diisi oleh 18 orang yang merupakan peserta dari pelatihan. Beberapa pernyataan yang ada pada kuesioner diukur dengan skala Likert 1-5. Pernyataan kuesioner digunakan untuk menilai 5 (lima) aspek yaitu pelayanan, kepuasan, pemateri, manfaat, dan protokol kesehatan. Pada lembar kuesioner juga disediakan saran dan kritik sebagai respon peserta pelatihan. Hasil kuesioner dengan pertanyaan dan hasil respon peserta disajikan pada tabel berikut:

\section{Tabel 1. Hasil Kuesioner}

\begin{tabular}{clccc}
\hline \multirow{2}{*}{ No } & \multirow{2}{*}{ Pertanyaan } & Sangat Baik & Bespon Peserta Pelatihan & Cukup Baik \\
\hline 1 & Pelayanan Pelatihan & 17 & 1 & 0 \\
2 & Kepuasan Peserta & 16 & 2 & 0 \\
3 & Pemaparan Materi & 16 & 2 & 0 \\
4 & Manfaat Pelatihan & 15 & 3 & 0 \\
5 & Pelaksanaan Protokol & 15 & 3 & 0 \\
\hline
\end{tabular}




\section{KESIMPULAN}

Pelatihan pembuatan media pembelajaran buku digital menggunakan flipbook memberikan pengetahuan baru kepada peserta sebagai pengajar pada SDIT Sullamul 'Ulum dalam membuat media pembelajaran yang baik dan dengan tampilan yang lebih menarik dibandingkan pembelajaran menggunakan papan tulis atau buku. Ketercapaian target dari materi yag disampikan sudah baik, karena materi dapat disampaikan secara keseluruhan dan praktek pada pelatihan yang dilakukan dapat diikuti oleh semua peserta kegiatan dengan bantuan dari anggota pengabdian kepada masyarakat dalam menyelesaikan masalah yang dihadapi peserta. Kemampuan peserta dalam menguasai materi sangat baik, berdasarkan hasil evaluasi kemampuan peserta menguasai materi yang diberikan. Peserta pelatihan mendapat pengetahuan baru serta meningkatkan wawasan tentang penggunaan flipbook sebagai media media pembelajaran buku digital yang menarik dan menyenangkan serta sangat optimal digunakan dalam pembelajaran dikelas.

\section{UCAPAN TERIMA KASIH}

Ketua dan anggota pengabdian kepada mengucapkan terima kasih kepada Yayasan Pendidikan Islam Sullamul 'Ulum, kepala sekolah dan segenap pengajar SDIT Sullamul 'Ulum yang sudah bersedia menjadi mitra pengabdian kepada masyarakat dan sangat antusias dalam mengikuti kegiatan pengabdian kepada masyarakat.

\section{DAFTAR PUSTAKA}

Andina, E., 2011. Buku Digital dan Pengaturannya. Jurnal Aspirasi, 2(2), p.95.

Ayuningtyas, A. et al., 2018. Pendampingan Pembuatan Bahan Ajar Bagi Guru Sekolah Dasar Islam Terpadu (SDIT) Salsabila Al Muthi'in Berbasis Multimedia dengan Menggunakan Microsoft Power Point. KACANEGARA Jurnal Pengabdian pada Masyarakat, 1(1), p.1.

Desyanti, Muztazihim Suhaidi, F., 2019. Meningkatkan kemampuan menghafal juz amma melalui media pembelajaran audio visual. Seminar Nasional Pemberdayaan Masyarakat, 1(Unri Conference Series: Community Engagement. Volume 1 ISSN 2685-9017), pp.297-303.

Fitria, H., 2018. PENGEMBANGAN STRATEGI PROBLEM BASED LEARNING PADA MATA KULIAH STRATEGI BELAJAR MENGAJAR. Jurnal Dosen Universitas PGRI Palembang.

Okra, R. \& Novera, Y., 2019. Pengembangan Media Pembelajaran Digital IPA Di SMP N 3 Kecamatan Pangkalan. Journal Educative : Journal of Educational Studies, $4(2)$, p.121.

Sari, F. et al., 2021. Pelatihan Pembuatan Media Pembelajaran Sempoa Berbasis Teknologi Informasi. ABDINE: Jurnal Pengabdian Masyarakat, 1(1), pp.14-19.

Sasmita, R.S., 2020. Pemanfaatan Internet Sebagai Sumber Belajar. Jurnal Pendidikan dan Konseling (JPDK), 2(1), pp.99-103.

Wahyuliani, Y., Supriadi, U. \& Anwar, S., 2016. Efektivitas Penggunaan Media Pembelajaran Flip Book Terhadap Peningkatan Hasil Belajar Siswa Pada Mata Pelajaran Pai Dan Budi Pekerti Di Sma Negeri 4 Bandung. TARBAWY : Indonesian Journal of Islamic Education, 3(1), p.22.

Wahyuningtyas, R. \& Sulasmono, B.S., 2020. Pentingnya Media dalam Pembelajaran Guna Meningkatkan Hasil Belajar di Sekolah Dasar. Edukatif : Jurnal Ilmu Pendidikan, 2(1), pp.23-27. 